DOI. 10.22219/fths.v4i2.16654

\title{
Efektivitas Ekstrak Daun Mangga Dengan Etanol 96\% sebagai Pengawet Alami Terhadap Masa Simpan Ikan Lemuru Pada Suhu Rendah
}

\author{
Bahtyar Hardyansyah Syihab1* ${ }^{*}$, Damat ${ }^{1}$, Joko Susilo Utomo ${ }^{2}$ \\ ${ }^{1}$ Program Studi Teknologi Pangan, Fakultas Pertanian Peternakan, Universitas Muhammadiyah \\ Malang, Malang Indonesia. \\ ${ }^{2}$ Balai Penelitian Tanaman Aneka Kacang dan Umbi, Malang, Indonesia. \\ *Corresponding author email: bahtyarsyihab17@gmail.com
}

\begin{abstract}
Indonesia is the highest fish producer in the world after China and Peru. Fish is a food that is easily damaged, one of which is lemuru fish, which is a fish with high production yields in Indonesia, therefore it is necessary to preserve lemuru. Preservation is a way to prevent damage to lemuru fish, one way is preservation using mango leaf extraction. Mango leaves contain substances that are antibacterial. This study aims to analyze the effectiveness of mango leaf extract as a natural preservative on the shelf life of lemuru fish at low temperatures. The research was carried out at the UPT Laboratory for Quality Testing and Development of Marine and Fisheries Products in Banyuwangi (PMP2KP). The research was conducted using factorial Completely Randomized Design (CRD) method. The mango leaf extract was treated with a dose of $0 \%, 10 \%, 20 \%$ and $30 \%$ soaking time for 30 minutes, then stored at low temperature $\left(5^{\wedge}{ }^{\circ} \mathrm{C}-10^{\wedge}{ }^{\circ} \mathrm{C}\right)$. Observations were made on day 0,2 and 4 for lemuru. The parameters observed included microbiology, namely TPC, chemistry, namely protein content, water content, $\mathrm{pH}$ and histamine and also organoleptic testing. The results showed that the use of mango leaf extract with a concentration of $20 \%$ in lemuru during low temperature storage had the longest shelf life of up to two days with a total bacterial value of $8.4 \times 10^{\wedge} 3 \mathrm{cfu} / \mathrm{g}$, the degree of acidity of 6.32 levels of protein. $17.28 \%$, water content of $73.31 \%$ and histamine $30.11 \mathrm{ppm}$.
\end{abstract}

Keywords: histamine, lemuru fish, mango leaf extract, moisture content, protein.

\begin{abstract}
Abstrak. Indonesia merupakan penghasil ikan tertinggi di dunia setelah China dan Peru. Ikan merupakan salah satu bahan pangan yang mudah rusak salah satunya adalah ikan lemuru merupakan ikan dengan hasil produksi cukup tinggi di Indonesia maka dari itu perlu pengawetan ikan lemuru. Pengawetan merupakan cara untuk mencegah kerusakan pada ikan lemuru, salah satu cara adalah pengawetan dengan menggunakan ekstraksi daun mangga. Daun mangga memiliki kandungan zat yang bersifat antibakteri. Penelitian ini bertujuan untuk menganalisis efektivitas ekstrak daun mangga sebagai pengawet alami terhadap masa simpan ikan lemuru pada suhu rendah. Penelitian dilaksanakan di Laboratorium UPT Pengujian Mutu dan Pengembangan Produk Kelautan dan Perikanan Banyuwangi (PMP2KP). Penelitian dilakukan menggunakan metode Rancangan Acak Lengkap (RAL) faktorial. Perlakuan ekstrak daun mangga dengan dosis $0 \%, 10 \%, 20 \%$ dan $30 \%$ lama perendaman 30 menit, kemudian disimpan pada suhu rendah $\left(5^{\circ} \mathrm{C}-10^{\circ} \mathrm{C}\right)$. Pengamatan dilakukan pada hari ke 0, 2 dan 4 untuk ikan lemuru. Parameter yang diamati meliputi mikrobiologi yaitu TPC, kimia yaitu kadar protein, kadar air, $\mathrm{pH}$ dan histamine
\end{abstract}


dan juga pengujian organoleptik. Hasil penelitian menunjukkan bahwa penggunaan ekstrak daun mangga dengan konsentrasi $20 \%$ pada ikan lemuru selama penyimpanan suhu rendah memiliki masa simpan yang paling lama yaitu hingga dua hari dengan nilai total bakteri 8,4 $\mathrm{x} 10^{3} \mathrm{cfu} / \mathrm{g}$, derajat keasaman 6,32 kadar protein $17,28 \%$, kadar air $73,31 \%$ dan histamine $30,11 \mathrm{ppm}$.

Kata kunci: kadar air, ekstrak daun mangga, histamin, ikan lemuru, protein.

\section{PENDAHULUAN}

Potensi perikanan laut Indonesia berupa ikan - ikan pelagis kecil, demersal dan pelagis besar. Berdasarkan data statistik perikanan tangkap Indonesia pada tahun 2012, potensi perikanan Indonesia sebesar 6,4 juta ton/tahun namun belum termanfaatkan secara optimal, pemanfaatannya masih dibawah 80\% (KKP, 2010). Ikan yang berasal dari perairan tawar maupun asin, tergolong bahan yang mudah mengalami kerusakan (high perishable product), dengan kandungan gizi yang tinggi akan memperbesar resiko kerusakan bahan. Kerusakan ini disebabkan oleh proses kimia maupun oleh aktivitas mikrobiologi. Salah satu usaha memperpanjang umur simpan ikan dapat dilakukan melalui proses penanganan dan pengolahan pasca panen yang tepat yaitu dengan cara pengawetan (Rasyid, 2001). Penelitian santoso (2017) ekstrak daun mangga dapat mengawetkan ikan air tawar namun keterbaruan dalam penelitian ini belum diketahuinya apakah ekstrak daun mangga dapat dijadikan pengawet ikan laut. Pada saat musim timur, hasil tangkapan nelayan melimpah dan terjadi kelebihan produksi serta tidak mendapatkan penanganan sebagaimana mestinya sehingga mengalami kerusakan dan pembusukan (Rostini, 2007).

Indonesia merupakan negara penangkap ikan terbesar ketiga di dunia setelah China dan Peru, selain itu Indonesia termasuk negara pemasok terbanyak keempat di dunia untuk produk perikanan yaitu sebesar 2 ton pada tahun 2011 (Fisheries and Aquaculture Department, 2014). Menurut Badan Pusat Statistik tahun 2012 jumLah hasil perikanan laut yang ditangkap di Indonesia per tahun semakin meningkat dari tahun 2004 yaitu sebesar 4,408 juta ton meningkat menjadi 5,435 juta ton pada tahun 2012. Hal ini membuat Indonesia kaya akan ikan terutama ikan lemuru. Menurut data statistika di sekretariat unit pengelolaan pelabuhan perikanan pantai (UP4), Muncar merupakan penghasil ikan terbesar di Jawa Timur, dengan produksi ikan tahun 2012 sebesar 10.813,422 ton. Tingginya potensi perikanan di Kecamatan Muncar akan direncanakan menjadi kawasan minapolitan.

Ikan lemuru yang melimpah jika tidak dilakukan penanganan pengawetan menyebabkan pembusukan karena mikroorganisme. Mikroorganisme dapat menimbulkan bermacam perubahan baik secara biokimiawi maupun fisikawi 
yang dapat menyebabkan timbulnya sifat-sifat yang tidak dikehendaki atau yang tidak disukai dan akhirnya menjurus pada kerusakan secara keseluruhan yaitu menjadi bahan pangan menjadi busuk (Santoso dkk., 2017). Pengawetan adalah cara untuk mencegah kerusakan pada ikan lemuru, salah satu cara adalah pengawetan dengan menggunakan ekstraksi daun mangga. Daun mangga memiliki kandungan zat yang bersifat anti bakteri. Ekstrak daun mangga diketahui memiliki kandungan senyawa alkaloid, fitosterol, resin, fenol, tanin, flavonoid, saponin dan terkandung juga senyawa mangiferin yaitu golongan xanton yang dapat digunakan sebagai senyawa antimikroba (Santoso dkk., 2017). Hal ini dapat menjadi solusi dalam pengawetan ikan lemuru.

\section{METODE PENELITIAN}

\section{Bahan}

Bahan yang digunakan dalam penelitian ini adalah daun mangga arumanis dengan keadaan tidak ada cacat fisik dan biologis dan ikan lemuru pada perairan yang sama. Bahan kimia yang digunakan dalam penelitian ini adalah tablet katalis kertas timbang bebas $\mathrm{N}$, batu didih, larutan asam borat 4\%, larutan $4 \mathrm{~g}$ H3BO3, larutan indikator methyl red 0,1\% etanol, green 0,1\% dalam etanol, asam sulfat (H2SO4) pekat p.a, hidrogen peroksida (H2O2 ) 30-35\% p.a, larutan natrium hidroksida - natrium thiosulfat ( $\mathrm{Na} 2 \mathrm{~S} 2 \mathrm{O} 3$ ), $\mathrm{NaOH}, \mathrm{Na} 2 \mathrm{~S} 2 \mathrm{O} 3$, larutan standar asam klorida \pm 0,2 N Metanol, aquadest, glasswool, $\mathrm{NaOH} 1 \mathrm{~N}, \mathrm{HCl}$ 0,1 $\mathrm{N}$, resin, asam perklora $\mathrm{H} 3 \mathrm{BO} 4,3 \% \mathrm{Na} 2 \mathrm{~B} 4 \mathrm{O} 7$, silcon anti foaming, indikator fenolftalein, indikator tashiro

Alat

Alat yang digunakan pada penelitian ini adalah oven, anrobic jar, autoclave, destruksi kjedhal, pH meter, selep, desikator, destilasi uap, show case, titrasi. Spektroflorometer, evaporator, watherbath, selep sedangkan bahan ikan lemuru dan daun mangga.

\section{Desain Penelitian}

Penelitian ini mengunakan RAL faktorial. Pelaksanaan penelitian ini dilakukan dalam 1 tahap yang meliputi pemberian ekstrak daun mangga terhadap ikan lemuru pada suhu rendah dengan lama penyimpanan 0 hari, 2 hari dan 4 hari dengan dosis $0 \%, 10 \%, 20 \%, 30 \%$.

\section{Ekstraksi Daun Mangga}

Ekstraksi yang digunakan adalah ekstraksi masserasi Santoso (2017). Daun mangga dilakukan pesortiran dengan dipilih daun mangga yang tidak ada 
cacat fisik dan biologis. Daun mangga sebanyak 10.000 g dikeringkan dengan cara dioven dan dijadikan serbuk. Serbuk daun mangga dimasukkan ke dalam bejana maserasi dan ditambahkan pelarut etanol 96\% sampai serbuk simplisia terendam, dan didiamkan sambil sesekali diaduk. Proses dilakukan dengan mengganti pelarut tiap 1×24 jam selama 3 hari. Hasil maserasi dikumpulkan dan disaring. Pemekatan dilakukan dengan evaporator menggunakan suhu $55^{\circ} \mathrm{C}$ dan kecepatan putaran 30 - 80 rpm. Ekstrak kemudian disimpan di dalam wadah kaca yang telah dibungkus dengan aluminium foil agar terhindar dari cahaya

\section{Penyimpanan Ikan Lemuru dengan Ekstrak Daun Mangga}

Ikan yang didapatkan dari nelayan secara langsung kemudian dibersihkan dan dihilangkan kepala, ekor dan kotoran kecuali ikan yang digunakan penelitian organoleptic tidak perlu menghilangkan kepala ekor dan kotoran. kemudian timbang 100 g per masing masing dosis yang akan digunakan yaitu dengan dosis $0 \%, 10 \%, 20 \%, 30 \%$. Rendam ikan dengan larutan aquades $100 \mathrm{ml}$ dan ekstrak daun mangga sesuai dosis selama 30 menit kemudian simpan di suhu rendah yaitu di showcase. Penelitian dilakukan pada hari ke 0, 2 dan 4. Parameter yang digunakan yaitu TPC, $\mathrm{pH}$, kadar air, protein, histamine dan organoleptik.

\section{Parameter Penelitian}

Analisa yang dilakukan pada penelitian pengawetan ikan dengan menggunakan ekstraksi daun mangga adalah mikrobiologi yaitu TPC (SNI 2015) Analisa kimia meliputi kadar protein (SNI 2019), kadar air (SNI 2015), pH (Hasrianti \& Nurasia, 2016) dan histamine (SNI 2016). Uji organoleptic (SNI 2015) meliputi kenampakan, aroma dan tekstur.

\section{Analisa Data}

Analisa data menggunakan ANOVA kemudian dilanjut dengan uji BNT a sebesar $\mathrm{P}<0,05$.

\section{HASIL DAN PEMBAHASAN}

\section{Nilai pH Ikan Lemuru}

Berdasarkan hasil ANOVA diketahui bahwa terdapat pengaruh nyata perlakuan dosis ekstrak daun mangga dan waktu penyimpanan terhadap $\mathrm{pH}$ ikan lemuru (Tabel 1). Berdasarkan hasil uji BNT 5\% diketahui bahwa sebesar 0,029 yang artinya ekstrak daun mangga berpengaruh nyata pada $\mathrm{pH}$ ikan lemuru $(\mathrm{P}<0,05)$. 
Tabel 1. Nilai pH ikan lemuru akibat pengaruh dosis ekstrak daun mangga pada beberapa variasi lama penyimpanan.

\begin{tabular}{rcccc}
\hline \multirow{2}{*}{ Faktor } & \multicolumn{4}{c}{ Dosis ekstrak daun manga } \\
\cline { 2 - 5 } & $0 \%$ & $10 \%$ & $20 \%$ & $30 \%$ \\
\hline Hari ke 0 & $6,07 \pm 0,01^{\mathrm{c}}$ & $6,10 \pm 0,02^{\mathrm{c}}$ & $5,97 \pm 0,04^{\mathrm{b}}$ & $5,90 \pm 0,02^{\mathrm{a}}$ \\
Hari ke 2 & $6,92 \pm 0,02^{\mathrm{g}}$ & $6,54 \pm 0,01^{\mathrm{f}}$ & $6,31 \pm 0,02^{\mathrm{e}}$ & $6,22 \pm 0,03^{\mathrm{d}}$ \\
Hari ke 4 & $6,98 \pm 0,04^{\mathrm{h}}$ & $6,57 \pm 0,01^{\mathrm{f}}$ & $6,57 \pm 0,03^{\mathrm{f}}$ & $6,33 \pm 0,01^{\mathrm{e}}$
\end{tabular}

Keterangan: Notasi yang sama pada nilai rata-rata menunjukkan tidak berbeda nyata pada taraf uji $5 \%$.

Tabel 1 menunjukan nilai $\mathrm{pH}$ pada dosis ekstrak daun mangga ikan segar berada pada kisaran di bawah netral, Menurut Ilyas (2010) menjelaskan nilai pH untuk ikan hidup sekitar 7,0 dan setelah ikan mati $\mathrm{pH}$ tersebut menurun mencapai 5,8-6,2 (Nurqaderianie $d k k$., 2016). Hal ini bertolak belakang dengan data Tabel 2 karena ekstrak daun mangga mengandung senyawa yang bersifat asam. Senyawa bersifat asam antara lain alkaloid, fitosterol, resin, fenol, tanin, flavonoid, saponin dan terkandung juga senyawa mangiferin yaitu golongan xanton yang dapat digunakan sebagai senyawa antimikroba (Somkuwar 2010). Ekstrak daun mangga bersifat asam sesuai dengan penelitian Setyawati (2018) yang menyatakan ekstrak daun mangga mempunyai $\mathrm{pH}$ rendah.

Data Tabel 1 di menunjukan semakin tinggi dosis ekstrak daun mangga mengakibatkan kenaikan pH semakin lambat, hal ini disebabkan oleh ekstrak daun mangga yang dapat mencegah pertumbuhan bakteri karena semakin tinggi $\mathrm{pH}$ maka semakin menurun mutu ikan ikan. Ikan yang sudah tidak segar $\mathrm{pH}$ dagingnya tinggi (basa) dibandingkan ikan yang masih segar. Hal itu karena timbulnya senyawa-senyawa yang bersifat basa misalnya amoniak, trimetilamin, dan senyawa volatile lainnya (Cara dkk., 2014). Ekstrak daun mangga dosis $30 \%$ mengalami penurunan $\mathrm{pH}$ hal ini terjadi karena ekstrak daun mangga mengandung alkaloid memiliki kemampuan sebagai antibakteri. Mekanisme penurunan $\mathrm{pH}$ pada ekstrak daun mangga dosis $30 \%$ yang diduga adalah dengan cara mengganggu komponen penyusun peptidoglikan pada sel bakteri, sehingga lapisan dinding sel tidak terbentuk secara utuh dan menyebabkan kematian sel tersebut (Puspita Sari dkk., 2015). Penulis berpendapat bahwa sesuai Tabel 2 semakin tinggi dosis semakin rendah $\mathrm{pH}$ yang didapatkan. Hal ini menyebabkan memperpanjang umur simpan karena semakin banyak senyawa antibakteri pada ikan lemuru sehingga dosis ekstrak daun mangga terbaik adalah $30 \%$. 


\section{Nilai Kadar Air Ikan Lemuru}

Berdasarkan hasil ANOVA diketahui bahwa terdapat pengaruh nyata perlakuan dosis ekstrak daun mangga dan waktu penyimpanan terhadap kadar air ikan lemuru (Tabel 2). Berdasarkan hasil uji BNT 5\% diketahui bahwa sebesar 0,029 yang artinya ekstrak daun mangga berpengaruh nyata pada kadar air ikan lemuru $(\mathrm{P}<0,05)$.

Tabel 2. Nilai kadar air ikan lemuru akibat pengaruh dosis ekstrak daun mangga pada beberapa variasi lama penyimpanan.

\begin{tabular}{rcccc}
\hline \multirow{2}{*}{ Faktor } & \multicolumn{4}{c}{ Dosis ekstrak daun manga } \\
\cline { 2 - 5 } & $0 \%$ & $10 \%$ & $20 \%$ & $30 \%$ \\
\hline Hari ke 0 & $69,72 \pm 0,07^{\mathrm{a}}$ & $71,47 \pm 0,03^{\mathrm{c}}$ & $72,92 \pm 0,02^{\mathrm{f}}$ & $73,44 \pm 0,03^{\mathrm{h}}$ \\
Hari ke 2 & $71,20 \pm 0,04^{\mathrm{b}}$ & $72,12 \pm 0,03^{\mathrm{d}}$ & $73,33 \pm 0,02^{\mathrm{g}}$ & $73,62 \pm 0,04^{\mathrm{i}}$ \\
Hari ke 4 & $75,43 \pm 0,01^{\mathrm{l}}$ & $72,39 \pm 0,01^{\mathrm{e}}$ & $74,40 \pm 0,03^{\mathrm{k}}$ & $75,43 \pm 0,01^{\mathrm{l}}$ \\
\hline
\end{tabular}

Keterangan : Notasi yang sama pada nilai rata-rata menunjukkan tidak berbeda nyata pada taraf uji $5 \%$.

Berdasarkan Tabel 2 semakin tinggi dosis semakin tinggi pula kadar air. Hampir sebagian besar tubuh ikan mengandung banyak air sehingga merupakan media yang sangat cocok bagi pertumbuhan bakteri pembusuk maupun mikroorganisme lain. Namun pemberian dosis ekstrak daun manga justru menambah kadar air hal ini disebabkan oleh kandungan air pada daun mangga itu sendiri seperti pada penelitian sebelumnya yang dilakukan oleh Silfiana Nisa Pramesti yang menyatakan bahwa ekstrak daun mangga mengandung 7,5\% kadar air (Permatasari, 2019). Semakin lama waktu penyimpanan semakin tinggi kadar air hal ini menyebabkan semakin lama penyimpanan semakin tinggi kadar air hal ini serupa dengan penelitian Ruksanan lama penyimpanan berpengaruh sangat nyata terhadap kadar air, total mikroba, aroma, dan tekstur ikan cepa asin kering yang dihasilkan (Ruksanan $d k k$., 2020). Tabel 2 menunjukan kadar air seluruhnya di bawah 80\%, Astawan (2006) menyatakan bahwa ikan mempunyai kandungan protein tertinggi setelah air. Kandungan air pada ikan sekitar 70-80\% dari berat daging. Kadar air yang tinggi akan mempermudah tumbuh dan berkembangnya mikroba pembusuk, selain itu protein pada tubuh ikan akan mudah mengalami kerusakan secara biologis serta kimiawi (Kaban dkk., 2019). Ekstrak daun mangga perlakuan t terbaik adalah $0 \%$.

\section{Nilai Kadar Protein Ikan Lemuru}

Berdasarkan hasil ANOVA diketahui bahwa terdapat pengaruh nyata perlakuan dosis ekstrak daun mangga dan waktu penyimpanan terhadap protein ikan lemuru (Tabel 3 ). Berdasarkan hasil uji BNT 5\% diketahui bahwa sebesar 
0,029 yang artinya ekstrak daun mangga berpengaruh nyata pada kadar protein ikan lemuru $(\mathrm{P}<0,05)$.

Tabel 3. Nilai kadar protein ikan lemuru akibat pengaruh dosis ekstrak daun mangga pada beberapa variasi lama penyimpanan

\begin{tabular}{rcccc}
\hline \multirow{2}{*}{ Faktor } & \multicolumn{4}{c}{ Dosis ekstrak daun manga } \\
\cline { 2 - 5 } & $0 \%$ & $10 \%$ & $20 \%$ & $30 \%$ \\
\hline Hari ke 0 & $19,79 \pm 0,06^{\mathrm{j}}$ & $18,96 \pm 0,01^{\mathrm{i}}$ & $18,55 \pm 0,02^{\mathrm{h}}$ & $18,38 \pm 0,04^{\mathrm{g}}$ \\
Hari ke 2 & $18,18 \pm 0,01^{\mathrm{f}}$ & $16,90 \pm 0,01^{\mathrm{a}}$ & $17,30 \pm 0,02^{\mathrm{c}}$ & $17,35 \pm 0,06^{\mathrm{c}}$ \\
Hari ke 4 & $17,68 \pm 0,01^{\mathrm{d}}$ & $17.91 \pm 0.05^{\mathrm{e}}$ & $17,69 \pm 0,01^{\mathrm{d}}$ & $17,10 \pm 0,01^{\mathrm{b}}$ \\
\hline
\end{tabular}

Keterangan : Notasi yang sama pada nilai rata-rata menunjukkan tidak berbeda nyata pada taraf uji $5 \%$

Tabel 3 menunjukan semakin tinggi dosis ekstrak daun mangga maka semakin tinggi protein hal ini terjadi karena ekstrak daun mangga karena menurut Rasjid dan Ismartoyo (2014) daun mangga memiliki komposisi kimia yaitu protein kasar 9,39\%, serat kasar 30,61\%, lemak kasar 2,86\%, abu 7,01\%, bahan ekstrak tanpa nitrogen (BETN) 50,13\%, kalsium 2,38\%, phosphor 0,23\%, 48,15\%, acid detergent fiber (ADF) 46,20\%, dan lignin 11,49\% (Santoso 2017). Tabel 3 semakin lama penyimpanan terjadi penurunan kadar protein. hal ini disebabkan protein adalah sumber makanan bagi mikrobiologi dan ekstrak daun mangga dapat mencegah aktvitas mikrobiologi. Pernyataan ini sesuai dengan Waluyo (2007) yang menyatakan bahan makanan merupakan medium pertumbuhan yang baik bagi berbagai macam mikroba. Keberadaan mikroba pada makanan ada yang tidak berbahaya bagi kehidupan manusia, beberapa mikroba mengakibatkan kerusakan pangan, menimbulkan penyakit, dan menghasilkan racun (Waluyo.L, 2007). Ekstrak daun mangga efektif menghambat penurunan protein pada dosis 20\%. Dosis 20\% pada Tabel 3 yang paling menghambat kerusakan protein. Hal ini disebabkan tehambatnya petumbuhan oleh ekstrak daun mangga yang cukup tinggi yaitu sebesar $20 \%$.

\section{Nilai TPC Ikan Lemuru}

Berdasarkan hasil ANOVA diketahui bahwa terdapat pengaruh nyata perlakuan dosis ekstrak daun mangga dan waktu penyimpanan terhadap TPC ikan lemuru(Tabel 4). Berdasarkan hasil uji BNT 5\% diketahui bahwa sebesar 0,029 yang artinya ekstrak daun mangga berpengaruh nyata pada TPC ikan lemuru $(\mathrm{P}<0,05)$. 
Tabel 4. Nilai TPC ikan lemuru akibat pengaruh dosis ekstrak daun mangga pada beberapa variasi lama penyimpanan.

\begin{tabular}{rllll}
\hline \multirow{2}{*}{ Faktor } & \multicolumn{4}{c}{ Dosis ekstrak daun manga } \\
\cline { 2 - 5 } & \multicolumn{1}{c}{$0 \%$} & \multicolumn{1}{c}{$10 \%$} & \multicolumn{1}{c}{$20 \%$} & \multicolumn{1}{c}{$30 \%$} \\
\hline Hari ke 0 & $19,79 \pm 0,06^{\mathrm{j}}$ & $18,96 \pm 0,01^{\mathrm{i}}$ & $18,55 \pm 0,02^{\mathrm{h}}$ & $18,38 \pm 0,04^{\mathrm{g}}$ \\
Hari ke 2 & TBUD & $7,45 \pm 0,07^{\mathrm{d}}$ & $8,35 \pm 0,07^{\mathrm{e}}$ & TBUD \\
Hari ke 4 & TBUD & TBUD & TBUD & TBUD \\
\hline
\end{tabular}

Keterangan : Notasi yang sama pada nilai rata-rata menunjukkan tidak berbeda nyata pada taraf uji $5 \%$;

TBUD (Terlalu Banyak Untuk Dihitung)

Tabel 4 menunjukan dosis ekstrak daun mangga 0\%,10\%,20\% dan 30\% tidak mengakibatkan jumLah awal bakteri menjadi lebih kecil. Hal ini dikarenakan bakteri masih dalam keadaan adaptasi karena terpaparnya ekstrak daun mangga yang mengandung zat antibakteri dan bersifat asam. Adaptasi stres atau respon bakteri terhadap stres, merupakan kemampuan sel bakteri untuk melawan situasi ketika populasi bakteri terpapar secara singkat oleh lingkungan fisik dan kimia pada tingkat suboptimal pertumbuhan (Muhammad Aulia Rahman Santoso, 2017).

Tabel 4 menunjukan dosis mengalami peningkatan jumLah bakteri semakin meningkat seiring dengan lamanya penyimpanan dikarenakan lingkungan yang optimal untuk pertumbuhan bakteri yang menyebabkan bakteri dapat tumbuh secara maksimal (Muhammad Aulia Rahman Santoso, 2017). untuk dosis $0 \%$ dan 30\% mengalami hasil TBUD hal ini disebabkan untuk dosis 0\% tidak ada perlakuan sehingga tidak ada senyawa yang menghambat pertumbuhan bakteri sedangkan dosis 30\% justru mengalami peningkatan sampai TBUD hal ini sesuai dengan penelitian Santoso semakin tingginya konsentrasi ekstrak daun mangga arumanis tidak memberikan masa simpan lebih lama. Kandungan protein kasar yang terdapat didalam ekstrak daun mangga sebagai sempurna dimanfaatkan oleh bakteri sebagai nutrisi, sehingga dengan bertambahnya ekstrak daun mangga arumanis akan meningkatkan nutrisi bagi bakteri pembusuk (Santoso, 2017).

Dosis 10\% dan 20\% mengalami penurunan TPC berkembang lambat hal ini disebabkan senyawa anti bakteri kandungan senyawa alkaloid, fitosterol, resin, fenol, tanin, flavonoid, saponin dan terkandung juga senyawa mangiferin yaitu golongan xanton yang dapat digunakan sebagai senyawa antimikroba (Khaerunisa dkk. 2015). Ikan lemuru menggunakan perlakuan dosis ekstrak daun mangga $10 \%$ adalah yang paling efektif, dikarenakan dosis tersebut menghambat pertumbuhan TPC. 


\section{Kadar Histamin Ikan Lemuru}

Berdasarkan hasil ANOVA diketahui bahwa terdapat pengaruh nyata perlakuan dosis ekstrak daun mangga dan waktu penyimpanan terhadap histamine ikan lemuru (Tabel 5 ). Berdasarkan hasil uji BNT 5\% diketahui bahwa sebesar 0,029 yang artinya ekstrak daun mangga berpengaruh nyata pada histamine ikan lemuru $(\mathrm{P}<0,05)$.

Tabel 5. Kadar histamin ikan lemuru akibat pengaruh dosis ekstrak daun manga pada beberapa variasi lama penyimpanan

\begin{tabular}{rcccc}
\hline \multirow{2}{*}{ Faktor } & \multicolumn{4}{c}{ Dosis ekstrak daun mangga } \\
\cline { 2 - 5 } & $0 \%$ & $10 \%$ & $20 \%$ & $30 \%$ \\
\hline Hari ke 0 & $45,29 \pm 0,67^{\mathrm{j}}$ & $32,07 \pm 0,12^{\mathrm{f}}$ & $24,58 \pm 0,07^{\mathrm{a}}$ & $26,80 \pm 0,16^{\mathrm{b}}$ \\
Hari ke 2 & $47,30 \pm 0,08^{\mathrm{k}}$ & $35,50 \pm 0,01^{\mathrm{h}}$ & $30,35 \pm 0,34^{\mathrm{e}}$ & $27,68 \pm 0,14^{\mathrm{c}}$ \\
Hari ke 4 & $48,62 \pm 0,35^{\mathrm{l}}$ & $37,55 \pm 0,18^{\mathrm{i}}$ & $32,90 \pm 0,31^{\mathrm{g}}$ & $29,10 \pm 0,79^{\mathrm{b}}$ \\
\hline
\end{tabular}

Keterangan : Notasi yang sama pada nilai rata-rata menunjukkan tidak berbeda nyata pada taraf uji $5 \%$

Tabel 5 menunjukan semakin lama penyimpanan maka semakin tinggi kadar histamine dalam penelitian yang dilakukan oleh Gaspersz (2012), mengenai penentuan kandungan histamine dalam daging Ikan lemuru berdasarkan waktu dengan metode spektrofotometri, telah dibahas tentang semakin lama waktu, kandungan histamin dalam sampel daging ikan juga semakin meningkat. Hal ini menggambarkan bagaimana laju penguraian histidin menjadi histamin oleh enzim histidin dekarboksilase yang berasal dari aktivitas mikroba (Hattu $d k k$, 2014). Histamine terbentuk oleh bakteri menurut penelitian fatuni dari Hasil penelitian ini menunjukkan dari 24 isolat diperoleh 6 jenis bakteri pembentuk histamin yaitu Klabsiella pneumonioe, Klabsiella oxytoca, Havnia alvei, Proteus vulgaris, Morganella morganii dan Enterobacter aerogenes. (Fatuni dkk., 2014). Semakin tinggi dosis ekstrak daun mangga menyebabkan berkembang lambat (Kurniasih, 2016)

Tabel 5 menunjukan bahwa seluruh sampel dibawah 50 ppm menurut SNI ikan segar mempunyai kadar histamine maksimal 50 ppm. Hal ini ekstrak daun mangga efektif mengahambat kadar histamine dan perlakuan terbaik pada dosis ekstrak daun mangga sebesar 30\%. Berdasarkan hasil ANOVA diketahui bahwa terdapat pengaruh nyata perlakuan dosis ekstrak daun mangga dan waktu penyimpanan terhadap organoleptik kenampakan ikan lemuru (Tabel 6).

\section{Organoleptik Ikan Lemuru}

Berdasarkan hasil uji BNT 5\% diketahui bahwa sebesar 0,029 yang artinya ekstrak daun mangga berpengaruh nyata pada organoeptik kenampakan ikan 
lemuru $(\mathrm{P}<0,05)$ sedangkan organoleptik tekstur, aroma dan lama hari tidak signifikan yang artinya tidak berpengaruh nyata pada organoleptik aroma, tekstur dan lama hari.

Tabel 6. Organoleptik ikan lemuru akibat pengaruh dosis ekstrak daun mangga pada beberapa variasi lama penyimpanan

\begin{tabular}{llll}
\hline \multirow{2}{*}{ Perlakuan } & \multicolumn{3}{c}{ Organoleptik } \\
\cline { 2 - 4 } & $\begin{array}{c}\text { Kenampakan } \\
(\mathrm{M} \pm \mathrm{SD})\end{array}$ & $\begin{array}{c}\text { Aroma } \\
(\mathrm{M} \pm \mathrm{SD})\end{array}$ & $\begin{array}{c}\text { Tekstur } \\
(\mathrm{M} \pm \mathrm{SD})\end{array}$ \\
\hline Dosis & & \\
\hline A1 $=0 \%$ & $5,17 \pm 0,75 \mathrm{ab}$ & $6,67 \pm 0,52$ & $6,50 \pm 0,55$ \\
$\mathrm{~A} 2=10 \%$ & $4,67 \pm 0,52^{\mathrm{a}}$ & $6,83 \pm 0,41$ & $7,00 \pm 0,00$ \\
A3 $=20 \%$ & $5,83 \pm 0,41^{\mathrm{b}}$ & $6,83 \pm 0,41$ & $6,83 \pm 0,41$ \\
$\mathrm{~A} 4=30 \%$ & $5,33 \pm 1,03 \mathrm{ab}$ & $6,50 \pm 0,84$ & $6,33 \pm 1,03$ \\
\hline BNT 5\% & 0,726 & $\mathrm{ts}$ & $\mathrm{Ts}$ \\
\hline Hari & & & \\
\hline B1 $=\mathrm{ke}-0$ & $5,13 \pm 0,83$ & $6,38 \pm 0,74$ & $6,88 \pm 0,35$ \\
B2 $=\mathrm{ke}-2$ & $5,38 \pm 1,06$ & $6,88 \pm 0,35$ & $6,38 \pm 0,92$ \\
B3 $=\mathrm{ke}-4$ & $5,25 \pm 0,46$ & $6,88 \pm 0,35$ & $6,75 \pm 0,46$ \\
\hline BNT 5\% & Ts & ts & ts \\
\hline
\end{tabular}

Keterangan:

1 = amat sangat tidak baik, $2=$ sangat tidak baik, 3 tidak baik, $4=$ agak tidak baik, $5=$ biasa saja (netral,), 6 = agak baik, 7 = baik, 8 = sangat baik, $9=$ amat sangat baik;

ts $=$ (tidak signifikan) panelis menilai antar sampel tidak ada perbedaan nyata; $\mathrm{M}=$ mean (rata rata)

Hasil signifikan pada kenampakan ikan disebabkan terjadi karena Perubahan-perubahan yang disebabkan oleh aktivitas enzim dan mikroorganisme terhadap protein dan membran sel menurunkan nilai hasil pengukuran akibat kerusakan ikan (Irianto \& Giyatmi, 2017). Hasil tidak signifikan pada perlakuan tekstur dan aroma tidak ada perbedaan yang nyata antara hari yang berbeda dan dosis yang berbeda Penggunaan daun mangga sebagai bahan pengawet dikarenakan daun mangga memiliki kandungan zat yang bersifat antibakteri. Ekstrak daun mangga diketahui memiliki kandungan senyawa alkaloid, fitosterol, resin, fenol, tanin, flavonoid, saponin dan terkandung juga senyawa mangiferin yaitu golongan xanton yang dapat digunakan sebagai senyawa antimikroba (Santoso dkk., 2017). Data Tabel 7 menunjukan bahwa ekstrak daun mangga efektif sebagai pengawet ikan lemuru. Panelis dominan menunjukkan tidak ada perubahan nyata. ekstrak daun mangga efektif dijadikan pengawet ikan

\section{KESIMPULAN}

Perlakuan terbaik dosis ekstrak daun mangga sebagai pengawet alami terhadap masa simpan mutu ikan lemuru pada suhu rendah adalah ekstrak daun 
mangga dengan dosis $30 \%$. Ekstrak daun mangga efektif sebagai pengawet alami terhadap masa simpan ikan lemuru pada suhu rendah.

\section{DAFTAR PUSTAKA}

Adawyah, R. 2007. Pengolahan dan Pengawetan Ikan. Jakarta: PT Bumi Aksara. Cynthia.A.A. 2012. Asuhan Gizi Nutritional Care Process. Yogyakarta: Graha IImu.

Bintoro, A., Ibrahim, A.M., \& Situmeang, B. 2017. Analisis dan Identifikasi Senyawa Saponin dari Daun Bidara (Zhizipus mauritania L.). Jurnal Itekima, 2(1), pp. 84-94.

Burhanudin, R. Moeljanto, S. Martosewojo, \& A. Djamali. 2011. Suku Scombriadea: Tinjauan Mengenai Ikan Tuna, Cakalang, dan Tongkol. LIPI.

Caballero, Benjamin, Paul Finglas, \& Fidel Toldra. 2015. Encyclopedia of Food and Health. Oxford: Academic Press.

Cahyadi. W. 2009. Analisis dan Aspek Kesehatan Bahan Tambahan Pangan. Edisi Kedua. Jakarta: Bumi Aksara.

Dika, F.A., Brahmana, E.M., \& Purnama, A.A. 2017. Uji Kandungan Protein dan Lemak Pada Ikan Bada (Pisces rasbora spp.) di Sungai Kumu Kecamatan Rambah Hilir. Jurnal Mahasiswa FKIP Universitas Pasir Pengaraian, 3(4), p.1-5.

Fatuni, Y.S., Suwandi, R., \& Jacoeb, A.M. 2014. Identification on Histamine Content and Histamin-Forming Bacteria of Boiled Badeng Slender Tuna. Jurnal Pengolahan Hasil Perikanan Indonesia, 17(2). https://doi.org/10.17844/jphpi.v17i2.8698

Fauzi, Sutari, W., Nursuhud, \& Mubarok, S. 2017. Faktor yang Mempengaruhi Pembungaan pada Mangga (Mangifera indica L.) Jurnal Kultivasi, 16(3), pp. 461-465.

Nurasia.H. 2014. Analisis Warna, Suhu, pH dan Salinitas Air Sumur Bor di Kota Palopo. Jurnal Universitas Cokroaminoto Palopo, 02, pp.747-753.

Hattu, N., Telussa, I., Fransina, E.G., Seumahu, C.A., \& Paais, S. 2014. Histamine Content in Processed Bullet Tuna (Auxis thazard) Stew with Various Concentration of NaCl. Ind. Journal. Chemistry. Res, 2, p.147-154.

Himawati, E. 2010. Pengaruh Penambahan Asap Cair Tempurung Kelapa Destilasi dan Redestilasi terhadap Sifat Kimia, Mikrobiologi, dan Sensoris Ikan Pindang Layang (Decaptereus spp) Selama Penyimpanan. Skripsi. Universitas Sebelas Maret. Surakarta.

Himelda, H., Wiyono, E. S., Purbayanto, A., \& Mustaruddin, M. 2013. Analysis of the Sardine Oil (Sardinella lemuru Bleeker 1853) Resources in Bali Strait. Marine Fisheries: Journal of Marine Fisheries Technology and Management, $2(2)$, pp.165-176.

Irianto, H. E., \& Giyatmi, S. 2017. Prinsip Dasar Teknologi Pengolahan Hasil Perikanan. Jakarta: Penerbit Universitas Terbuka. 
Kalista, A., Redjo, A., \& Rosidah, U. 2018. Analisis Organoleptik (Scoring Test) Tingkat Kesegaran Ikan Nila Selama Penyimpanan. Jurnal Fishtech, 7(1), pp.98-103. https://doi.org/10.36706/fishtech.v7i1.5985

Kurniasih, R. 2016. Pengaruh Konsentrasi Ekstrak Etanol Daun Mangga Arumanis Muda (Mangifera indica L.) terhadap Hambatan Pertumbuhan Bakteri Streptococcus mutans in Vitro. Skripsi. Universitas Muhammadiyah Surakarta.

Maidika, D., Siburian, J., \& Hamidah, A. 2016. Study of Fish Types at Parit 1 Kuala Tungkal Market for High School-Biology Popular Scientific Book. Bioedukasi: Jurnal Pendidikan Biologi, 9(2), pp.27-36.

Santoso, E. L. \& E. A. 2017. Efektivitas Ekstrak Daun Mangga sebagai Pengawet alami terhadap Masa Simpan Filet Nila pada Suhu Rendah. Jurnal Perikanan dan Kelautan. 8(2).

Ningsih, D. R. 2017. Ekstrak Daun Mangga (Mangifera indica L.) sebagai Anti Jamur terhadap Jamur Candida albicans dan Identifikasi Golongan Senyawanya. Jurnal Kimia Riset, 2(1), pp.61.

Pasaraeng, E., Abidjulu, J., \& Runtuwene, M. R. J. 2013. Pemanfaatan Rimpang Kunyit (Curcuma domestica Val) Dalam Upaya Mempertahankan Mutu Ikan Layang (Decapterus sp). Jurnal MIPA, 2(2), pp.84. https://doi.org/10.35799/jm.2.2.2013.1992

Permatasari, S. N. 2019. Determinasi dan analisa proksimat daun benalu pada pohon mangga arum manis di Ketintang Madya Surabaya. Journal of Pharmacy and Science, 4(2), pp. 77-83.

Pianusa, A. F., Sanger, G., \& Wonggo, D. 2016. Kajian Perubahan Mutu Kesegaran Ikan Tongkol (Euthynnus affinis) yang Direndam dalam Ekstrak Rumput Laut (Eucheuma spinosum) dan Ekstrak Buah Bakau (Sonneratia alba). Jurnal Teknologi Hasil Perikanan. 4(2), pp.66-74. https://doi.org/10.35800/mthp.4.2.2016.12927

Puspita Sari, P., Susanah Rita, W., \& Puspawati, N. 2015. Identifikasi dan Uji Aktivitas Senyawa Tanin dari Ekstrak Daun Trembesi (Samanea saman (Jacq.) Merr) sebagai Antibakteri Escherichia Coli (E. Coli). Jurnal Kimia. 9(1), pp. 27-34.

Ruksanan, Rustanari, Nggolele, S., \& Dahniar. 2020. Pengaruh Lama Penyimpanan pada Suhu Kamar terhadap Kualitas Ikan Cepa Asin Kering. Sultra Journal of Agricultural Research, 1(1), pp.25-35.

Santoso, M. A. R., Liviawaty, E., \& Afrianto, E. 2017. Efektivitas Ekstrak Daun Mangga sebagai Pengawdkkami terhadap Masa Simpan Fillet Nila pada Suhu Rendah. Jurnal Perikanan dan Kelautan.,8(2), pp. 57-67.

Simanjuntak, P.F. 2012. Pengaruh Penilaian Prestasi Kerja terhadap Motivasi Kerja Karyawan PT Putrimega Asri Indah. Medan.

SNI. 2015. Pedoman Pengujian Sensori pada Produk Perikanan. SNI No. 2346:2015(a). Badan Standardisasi Nasional. Jakarta.

SNI. 2015. Penentuan Angka Lempeng Total (ALT) pada Produk Perikanan. Badan Standardisasi Nasional. Jakarta. 
SNI. 2015. Pengujian Kadar Air pada Produk Perikanan. Badan Standardisasi Nasional. Jakarta.

SNI. 2016. Penentuan Kadar Histamin dengan Spektroflorometri dan Kromatografi Cair Kinerja Tinggi (KCKT) pada Produk Perikanan. Badan Standardisasi Nasional. Jakarta.

SNI. 2019. Penentuan Kadar Protein dengan Metode Total Nitrogen pada Produk Perikanan. Nanotechnology. 27(9). Badan Standardisasi Nasional. Jakarta.

Sopandi, T dan Wardah. 2014. Mikrobiologi Pangan Teori dan Praktik. Maya(ed). Andi Yogyakarta.

Susilo, E. 2015. Variabilitas Faktor Lingkungan Pada Habitat Ikan Lemuru Di Selat Bali Menggunakan Data Satelit Oseanografi dan Pengukuran Insitu. Omni-Akuatika, 14(20), pp.13-22.

Waluyo. L. 2007. Mikrobiologi Umum. UMM Press. Malang.

Wibowo, I.R., Darmanto, \& Anggo, A.D. 2014. Pengaruh Cara Kematian dan Tahapan Penurunan Kesegaran Ikan terhadap Kualitas Pasta Ikan Nila (Oreochromis niloticus). Jurnal Pengolahan dan Bioteknologi Hasil Perikanan, 3(3), pp.95-103.

Wirakusumah. 2007. Jus Buah dan Sayuran. Penerbit Swadaya. Jakarta. 